\title{
Rhetoric and Doctrine in Donne's Holy Sonnet IV
}

\author{
S. P. ZITNER
}

The sonnet beginning "At the round earths imagin'd corners" - fourth in Dame Helen Gardner's numbering of Donne's Holy Sonnets, ${ }^{1}$ seventh in Sir Herbert Grierson's - has had almost as distinguished a career in the lists of commentary as in the civil quiet of anthologies. I.A. Richards used it for his Cambridge experiments in Practical Criticism, where it attracted the highest number of non-committal "votes." 2 It figures importantly in Dame Helen's account of the Holy Sonne is as illustrative of Donne's progress in doctrinal matters and of his Ignatian method in composition. It is analysed by Stanley Archer in his questioning of the relevance of that method to an understanding of Dorne's poems, and employed by Murray Roston as an instance of Donnf's mannerism. It is, for Wilbur Sanders, "eloquently modulated" and "spine-tingling" (perhaps the Hollywoodism is half-way to dispraise), $\mathrm{t}$ ut finally not the product of "a genuinely religious encounter." 3 More vvidence could be added to qualify Richards' observation - upon review ing student protocols on the sonnet - that "It is in the nature of some performances that they leave the spectator feeling rather helpless."

After responding to the contrast between the grand evocation of general Judgement in the octave and the private quiet of the sestet's plea for instruction in repentance, and to the apparent logic that connects them, one hesitates over the tone and import of at least three passages. Even if these hesitations can be accommodated reasonably well to some interpretation of the poem, the passages remain a matter of concern because they seem to point outward to the preoccupations of Donne's Pseudo-Martyr and of several elegies - all probably written within a year of the sonnet. It is as though one had seen beneath the surface of a stream not the expected smooth rocks, but the jagged outfall of a quite different event.

"Round earths imagin'd corners," "Shall behold God, and never tast deaths woe," "for that's as good/ As if thou hadst seal'd my pardon, with thy blood": these are the occasions of hesitation. First, why the 
playing off of "round earth" against "imagin'd corners"? If one thinks of this as a stylistic tic, a merely characteristic turn of Donne's wit, one may conclude with Sanders that it is "chirpy" - an inopportune levity made possible - as he goes on to conjecture - because "Religion, in Donne's sonnet, feels like something made" as distinct from a "religiousness that grows spontaneously out of the natural man." This suggestion raises issues to which one wants to return. But it prompts first another look at the tone of the line. The common gloss is Revelation 7.1: "And after these things I saw four angels standing on the four corners of the earth, holding the four winds of the earth...." The "things" are earthquake, falling stars and other signs that "the great day of his wrath is come." Donne seems to have been fond of the passage, which he employs in three sermons. ${ }^{4}$ That the corners are imagined should suggest caution in taking up Shawcross's idea ${ }^{5}$ that the conventional iconographic contrast between roundness (perfection) and angularity (imperfection) applies here. Donne of course knows the iconographic usage and employs it in "Upon the translation of the Psalms," the elegies on the death of Prince Henry and Lady Bedford, "The Legacie," and elsewhere. But when he writes of the roundness of the earth, as in "A Valediction of Weeping," "The Comparison," "To Sir Edward Herbert at Julyers," and in "The First Anniversary" (in which he also employs the circle iconographically: $11.268,275$ ), his use is literal, and probably for the reason suggested there (285ff), that "The worlds proportion disfigur'd is" after the Fall. The emphatic conceptual contrast in the sonnet is between a roundness that is self-evident, or at least requires no qualifivation, and corners that need the qualifying word "imagin'd." Whether the imagining is attributed to the speaker or to Revelation, it prepares for what follows, making the vision of Judgement seem, for the duration of the line at least, more provisional than the matter-of-factly presented :ound earth. If we did not know what followed the first line of the poem we might as readily expect a send-up as the apocalypse. The tone of the line is wryly serious, and its rhetorical strategy like that of Browne's title Religio Medici, which encourages in the reader a paradoxical acceptance of the particular authority of the author, an acceptance depending on expectations aroused by the contemporary overlap of the terms "empiric" and "physician." With his characteristic kicking at the goads of genre - here the religious lyric - Donne begins by seeming to put Revelation into question, even as he employs its imaginings.

But the line may be viewed in other ways. "The trumpets," as Professor Stampfer puts it, "are literally blown at an imagined place. This assertion of reality in the teeth of bewilderment we call the metaphysical shudder. By it, we mean a grasp at complex truth in a universe crumbling to hewilderment and triviality." ${ }^{2}$ This bewilderment Stampfer localizes 
in "contradictions" between the finite and infinite worlds at which Donne "impossibly, simultaneously grasps." The triviality presumably arises either from one's speculation on the effects of living with bewildering contradictions long unresolved, or from the whole intellectual situation of Jacobean England. On this view, we are meant to take the bewilderment as felt (Donne's), rather than rhetorically intended (the reader's), and thus as the vehicle of Donne's "stark unease" rather than a strategy based on some assured outlook. Not so, according to Professor Roston:

Intellectually Donne now knows beyond question that the earth is round, and acknowledges unhesitatingly that the traditional four-cornered world of biblical cosmology exists only as an imagined entity. Yet it is that imagined world which he requires as the setting for his awesome vision of Judgement Day. Hence, after a brief nod to the empirically proved fact. . .the imaginative power of the poem takes command, reducing it to a trivial technicality before the excited rhythms inspired by the apocalyptic vision.?

On Stampfer's view apparent contradictions trivialize all; on Roston's the triviality is localized in what is known through observation. Donne is not grasping at the finite; he holds it and rejects it. "The command 'blow' reverberating into infinity as it sweeps across the run-on line serves to drown the pettiness of any empirical objection to the visionary call of Judgement." "Ultimate imaginative reality" - to continue with Roston's words - overcomes "the restrictions of a cold scientism." Actuality is dematerialized; the perspectives of time and space lose their authority as they are subjected to spiritual truth: such is the manner, or rather the mannerism, of the sonnet. The first and third interpretations see rhetorical or stylistic control; the second helplessness and disorder. The contrasts as stated here are perhaps more extreme than one should insist on. The sonnet obviously shows a high degree of artistic control and - on the other hand - is written well before Donne works out his beliefs and commitments or makes his peace with them. Indeed, one might say that an early impression of disorder is the means by which mannerist art gains its effects, just as the commitments Donne later reaches validate the "irresolution" he ascribes to himself in Pseudo. Martyr. ${ }^{8}$ In any case, though, these differences in interpretation suggest the need to determine more precisely how style and rhetoric, feeling and ideas cohere or cancel in the poem. And this in turn leads to its later lines, which have received less attention than its spectacular opening. As Donne himself puts it,

In all metricall compositions,... the force of the whole piece, is for the most part left to the shutting up; the whole frame of the poem is a beating out of a piece of gold, but the last clause is as the impression of a stamp, and that it is that makes it currant. ${ }^{9}$ 
Before the last clause, however, there are lines whose interpretation must affect a reading of it. Lines 5 to 8 complete the octave with a catalogue of death's variety. Dame Helen calls them an "enumeration of opposites." "First come those who have died suddenly, in multitudes - by war and pestilence; then those who have died one by one - by natural decay." There follow those destroyed by the will of others; by their own will, by "the deliberate processes of law," and by chance. The final category comprises those who will "behold God and never tast deaths woe."10 Yet the effect of these lines is less that of deliberate order and logicality than of wit, and of an arbitrariness (that is, the absence of an obvious principle of sequence), which emphasizes a multiplicity in death's means answering to the numberlessness of those called to Judgement. The juxtapositions of "agues" and "tyrannies," "law" and "chance," have prompted Sanders (p. 132) to see the catalogue as a series of "witty asides," and Stampfer (p. 247) as a set in which "All historic time is reduced to a catalogue of killings." But the lines are neither diversion nor protest. Rather they seem to express two tendencies at odds: the metrical excitement of a sequence of words in emphatic monosyllabic isolation as in, say, 11.2-4 of Shakespeare's sonnet 129, but played against an emotiveness and specificity almost evenly diminishing from the heavily loaded opening words "war, dearth, age" to the abstract and unpictorial law and chance. The tone is one of excitement mastered.

This cool tumult of temporal possibility is framed by statements from another realm of discourse. It is preceded by "All whom the flood did, and fire shall o'erthrow" and followed by "you whose eyes,/Shall behold God, and never tast deaths woe" - both allusions to the imagined world of Biblical apocalypse. This seems a recapitulation of the strategy of the first line, which treats the known and the imagined with an evenhandedness that suggests also the speaker's doctrinal or emotional distance from his materials. Though all members of the catalogue are causes of death, they are not to be bundled together as "wages of sin" without some irony or qualification. Biblical flood and fire provide temporal brackets for the deaths of secular history. But where in time is one to place the sort of death - if that is what it is - in beholding God without death's woe? The close of the octave seems to prepare for the quiet hopefulness of the sestet by lowering the apocalyptic intensity, something already begun in the cool abstractness of "law" and "chance." But the impression of lowered intensity is perhaps an effect of current remoteness from Christian eschatology. The last lines of the octave seem to join the apocalyptic with the immediate. The speaker now addresses those who will be alive at the Second Coming, those for whom Judgement is a possibility that may overtake them in the midst of literal existence. And the reader is perhaps one of these. A point to be made about 


\section{0 / Renaissance and Reformation}

the rhetoric of the octave is that the alienating grandeur of its vision may well culminate in the suggestion of the reader as possible actor on the terrific scene, with of course the implied compliment of his inclusion among the saved. This is, at the very least, a risky suggestion, but Donne's writing gives us examples of surprising shifts in tone and strategy, and of the particular kind of address suggested here.

Donne employs this strategy of immediacy and compliment in his Easter sermon of 1622 on the text from 1 Thessalonians 4.17: "Then we which are alive, and remain, shall be caught up together with them in the clouds, to meet the Lord in the ayre; and so shall we be ever with the Lord."11 The Pauline text is addressed to those expecting the parousia in their own life-time, as are other texts Donne uses. But though he mentions the historical context, the sermon largely ignores it; no historical barrier is set up between the text and the congregation of 1622 . Modern eschatology follows Dodd, Bultmann and others in turning the Last Days into metaphor. ${ }^{12}$ The Christian who truly accepts Christ is "out of the world" yet remains "within history"; the End refers to meaning, not to time. Paul had to reassure the Thessalonians, troubled by delays in the Second Coming, through distinguishing between its immediacy and its imminence. But by 1622 Judgement had not yet become as distant as it is, say, in Claudel, or as figurative as in Yeats, or as curious and awkward an idea as it is now even in some modern theological writings. "What if this present were the world's last night?" was a question to be asked with some urgency. Apostolic certainties had become apprehensions, then hypothetical questions, and finally metaphors. It would be rash to guess how much belief in the imminence of the Second Coming remained by the early 1600's. But we can conclude - if only from the number of times he uses the idea - that Donne thought it would provoke in enough of his audience a shudder rather than a query; this despite Sermon LXXIII, where the world's end seems put off to the year 2000 .

The Easter sermon of 1622 is also relevant for the final phrase of the octave - the "woe" from which the virtuous alive at Judgement will escape. In the Second Part of the sermon (p. 75), Donne argues out the interpretations of 1 Corinthians $15.51 \mathrm{ff}$. and especially of the phrase "we shall not all sleep." He finally disagrees with St. Chrysostom's view of the passage as implying that those alive at the Second Coming will not die. "We shall have a present dissolution of body and soul, and that is truly death...we shall die, and be alive again, before another could consider that we were dead...." The sermon, however, seems to have it both ways: we die, but though we are not resurrected in "an absolute instant," the resurrection does take place "In raptu, in an instant." The difference between those dead before Judgement and those then living 
is that for the latter the body, "without resolving into dust," somehow proceeds, and "the first step it makes, is into glory." (p. 76) The Third Part of the sermon begins with the observation that "Of any Resurrection of the wicked, here is no mention. Not that there is not one...," but they rise only that "they may fall lower."

Possibly Donne already had in mind such views when the sonnet was written. In any case, there is no warrant for the notion that the end of the octave merely reflects Donne's grasp at some escape from the anxieties that accompanied his preoccupation with death. We will return to the question of Donne's altering views of the state of the virtuous souls at the time of Judgement when we come to consider the composition of the sonnet as a whole. But for the moment enough has been said to permit us to go on to a consideration of the sestet.

The contrast between octave and sestet is generally acknowledged to be a triumph of texture and tone. But it has not escaped several sorts of censure. For Sanders (p. 132) the phrase "'above all these, my sinnes abound' sounds complacently pious - related in feeling to the obligatory long-faces people put on in church-porches as they adjust their head-gear." This not only skims over Donne's conditional "if," but ignores the character of penitential rhetoric from Innocent III onward. ${ }^{13}$ The idea of abundant grace is conventionally coupled with the extremity of sin, as in Bunyan's title Grace Abounding to the Chief of Sinners. The tradition rests in part on such texts as Genesis 32.10: "I am not worthy of the least of all thy mercies...." on which Donne himself preached. ${ }^{14}$ Donne's "if," however, may relate to a contemporary problem. One of the differences between Roman orthodoxy and the views of the Reformers was the latter's objection to what they thought the excessively exalted view of man held by the Roman church. ${ }^{15}$ Since this view underlay the practice of indulgences, the quarrel over man's status generated more heat than one might have expected of a philosophic or temperamental disagreement on the question. Donne's poetry provides us with vivid images of both human excellence and human baseness. In the sermons, however, he rests with neither Roman hopefulness nor Reformist pessimism about man. He has, as Mueller puts it, "a more favorable judgement of the natural, unregenerate man than the Reformers do," but avoids the Pelagian error of depending too much upon natural faculties. ${ }^{16}$ Further, Donne has no sympathy for attitudes supporting the practice of indulgences. It is perhaps this sense of being in a middle position that may well have led Donne to use "if" rather than the "since" that would better accord with the long-faced complacency Sanders ascribes to the lines. In any case, the conditional form must be linked with the tentativeness in the "As if" of the last line and with the plea for instruction in the line before. 
The greatest difficulties of interpretation, however, centre on these final lines:

Teach me how to repent; for that's as good

As if thou 'hadst sealed my pardon, with thy blood.

Dame Helen (p. 68) glosses the couplet as follows: "True repentance is a guarantee that the general pardon purchased by Christ's blood is sealed to a man individually." This illuminates the meaning that perhaps ought to be primary in the lines, but it does not deal (as perhaps no paraphrase could), with the ambiguities and tone of Donne's statement. It is these rather than the doctrinal point which create problems in interpretation, and - for some readers - the sense that the sonnet is most problematical where it should be clearest. "Teach me how to repent" lacks the force and the implication of spiritual exertion of the gloss's "True repentance." It is this that prompts Sanders to observe that Donne's God seems here so much a part of the known world that the ways to Him may also be "perfectly known." Second, the gloss lacks the tentativeness of "as if," an effect which gains some force from the "if" in line 10. Finally, the gloss does not seem to play off repentance and the crucifixion as do the lines themselves. This rather surprising contrast centres on the rhymeword "good," which means here primarily efficacious, though it also picks up the ethical meaning as well. If we try to tease out the implications of the lines we get some odd threads. Is there, for example, any scale or context in which an individual's repentance might be considered either as efficacious in bringing about his pardon, or as important a moral action, as a divine self-sacrifice that establishes the possibility of pardon in the first instance, and then goes on to guarantee it to the individual? Further, may one not conclude that in using the word "sealed" to indicate an assured individual pardon, Donne evokes an idea of contracts that leaves the crucifixion as general pardon - a rather empty legal instrument - an unsealed draft? In the last lines Donne has imagined a crucifixion with wholly personal implications, and in doing so has underlined the ambiguities that trouble popular understanding of the implications of the crucifixion for general and personal pardon, and has left the impression that the central event of Christianity has been displaced, forced in to the shade. The lines are both surprising and appropriate to the rest of the poem; this must be their defense and explanation. Yet Donne's invention of a special crucifixion seems also the wishful simplification of a doctrine that did not yet yield up the comfort of personal assurance. (A further possibility: that the teaching of repentance - rather than the repentance itself - is to be played off against the crucifixion does not seem to me to be a strong one.) Stampfer calls the spirit of the lines "antinomian" and perhaps this is right for their effect. The poem 
seems to conclude as it began - with something accessible to experience (albeit with the guidance of doctrine), being weighed against something more remote because it depends on a problematic use of doctrine and belief. The rhetorical strategy of what might be called the lay expression of religious conviction, begun modestly with a round earth contrasted with imagined corners, concludes with the daring use of the central fact of Christianity as a foil for private sentiment.

Some doctrinal points are in order here. The Donne of the sermons would probably not have entertained the idea that repentance was as efficacious as Christ's sacrifice. ${ }^{17}$ Donne treats the redemptive process at many points in the sermons. His conception of the qualified role of repentance - imposed by Original Sin - is suggested in the following passage: "but in the brightest light of the Gospell, in the brightest light of grace, in the best strength of Repentance, and our best resolutions to the contrary, yet we stumble, and fall againe. ..."18 Realizing our weakness, God sends the Holy Ghost as guide and He works for the salvation of man through Christ's sacrifice. Repentance is, of course, man's obligatory part, but the blood of Christ and human effort are not to be played off one against the other. They must work in conjunction and, indeed, if there is to be a priority in efficacy, it is on God's side. We are not to make the Pelagian mistake of thinking "Naturall faculties joyntCommissioners with Grace," or the other mistake of denying these faculties to be "subordinate servants and instruments of Grace." 19 I am less concerned with the orthodoxy or heterodoxy of Donne's views in the sonnet than with using orthodoxy as a norm against which to fix the rhetorical strategy of the poem. Normalizing the import of the last lines to accommodate them to orthodox views may momentarily obscure that strategy. But the current ignorance on doctrinal points turns out for once - to be little barrier to understanding. The shock or hesitation Donne seems to have intended asserts itself to many modern readers.

This anomaly of doctrine returns us to a larger issue, the course of Donne's religious thought; and to an issue larger still, our expectations in reading religious poetry. Dame Helen Gardner, always useful on both topics, has pointed out the inconsistency of Donne's views in Sonnet IV with his views in the sermons. ${ }^{20}$ Donne "usually tells his congregation not to inquire too curiously into such matters" as Election or Reprobation; they are "indifferent" questions. But he "insists again and again, with a curious and sometimes hardly relevant exactitude, on the nature of the immortality of the soul, and particularly on precisely what happens to the soul at the moment of death." At death the virtuous soul "goes immediately to heaven to enjoy the full vision of God, and awaits in heaven the full consummation of its joy when it will be reunited with the body at the Last Day." Donne's recurrence to this point a "remark- 
able number of times" suggests that it was "for some reason, a matter of importance to him," especially in the face of his acknowledgement in the Devotions that the matter was in dispute, and his probable knowledge that Calvin himself thought the question indifferent. In Sonnet IV Donne's virtuous souls are bidden to arise from death. They have not been waiting in bliss; only the living are there accorded the almost instant beatific vision. However, the early editions, supported by the manuscripts of Group II, do give us lines in Sonnet III that are consistent with the doctrine of the sermons. But manuscripts of Sonnet III from Dame Helen's Groups I and III and W read the seventh line as "Or presently, I know not, see that Face." This expression of doubt, Dame Helen observes, "is the more impressive in that the sestet assumes that the soul receive[s] its final judgement at death. ..." She goes on to conclude that the "reading of these manuscripts must be the original reading, which Donne amended. . .some time after he had made up his mind on the points." She argues later that "The truth would seem to be that when he wrote these sonnets Donne had given no serious thought to the matter at all," and then points out that the immediate transport of the virtuous soul to heaven - the view of the sermons - is first expressed in Pseudo-Martyr, on which Donne worked in the latter half of 1609. This information has led to the acceptance of the first half of that year as the time of composition of the six eschatological sonnets.

Perhaps one can discover evidences of Donne's altering views even closer to his composition of the sonnets, despite the difficulties of establishing an exact chronology. Lady Bridget Markham, a cousin of the Countess of Bedford, died at Twickenham on May 4, 1609. Donne's elegy on her death was probably written shortly after. Some lines seem to bear on the idea of immediate judgement. Donne's intended compliment,

Soe much did zeale her conscience rarefie,

That, extreme truth lack'd little of a lye (11.45-46),

makes the lady seem tiresome indeed, but we are assured that her soul, freed from the body by death, like the cherubs of Moses in Exodus 25, surpasses all speed, and is "already in heaven." (11.49-51) An elegy on Mrs. Bulstrode, who died on August 4, 1609, tells us that "Her Soule is gone to usher up her corse." (1.46) And line 51 of "Elegie: Death," possibly also on Mrs. Bulstrode, "Angels did hand her up, who next God dwell," again implies immediate judgement. Of course this is conventional stuff; even Falstaff seems to have gone at once to Arthur's bosom. The very idea of immediate judgement is so pervasive, congenial, and palliating a notion that declaring the state of souls after death to be an indifferent question may well have been a prudential recognition 
that not even theology can hold back the sea - whatever the import of the question for controversies between Rome and Reform. What seems to emerge from Donne's writings during all of 1609 is the picture he gives us in the preface to Pseudo-Martyr: that of a man concerned about the "irresolution" of his beliefs, but delaying "determination, till I had, to the measure of my poore wit and iudgement suruayed and digested the whole body of Diuinity, controuerted between ours and the Romane Church." 21 While there is no hard evidence to contradict the view that Donne had simply not thought about the particular question of the state of the soul after death, Donne's particular concern with death and judgement and the fact that Donne had helped Morton produce a series of polemics between 1605 and 1607 which employed many of the authorities he uses in Pseudo-Martyr, allow us to argue that the opposite view may be more likely. The manuscripts of Sonnet III and the hints from the elegies indicate that Donne was aware of alternatives and could employ them, though precise dates cannot be assigned to any of the poems. But perhaps one can go further.

The apocalypse in Sonnet IV is on most Anglican views unexceptional. The apocalytic view we get after Donne moves closer to formal affiliation and the taking of Anglican orders is, while not un-Anglican, closer to a Romanist position. ${ }^{22}$ The psychology of conversion is problemati$\mathrm{cal}$; even more so is the process of disaffiliation and "irresolution" that Donne underwent, further complicated as it was by long deliberation and a careful concern for both in tegrity and appearances, and by Donne's refusal to lapse into scepticism. Despite all this, one is tempted to conjecture that earlier in his journey toward Anglican orders there was for Donne a kind of safety in the more conventional side of an indifferent question, whereas later on he could feel free enough to accept on such an issue views more in accord with his temperamental needs. In any case, the tensions in this process of creeping self-conversion seem to be reflected in the rhetorical strategy of Sonnet IV. That sonnet dramatizes the situation of one who is wholly committed to a Christian view, but sees his attachment to literal reality and his placement among dogmatic alternatives as a continuing source of unease to be worked into harmony. The sonnet plays observation and authentic feeling against doctrine and imagining, asserts emphatically the part of the believer yet seems to keep doctrine at a distance, even seems to denigrate it - and all this without falling into scepticism. The sonnet provides a picture of hesitation, not on the brink of belief, but within it.

On such an interpretation, the absence of a Wordsworthian natural piety, "a religiousness that grows spontaneously out of the natural man" - which Sanders (pp. 111ff) and others lament in some of the Holy ionnets - seems not to the point. At worst such views can lead to the etting up of a norm of parochial realism, and to according poetic valid- 
ity only to religious expressions that arise in a pre- or post-doctrinal context (if we can imagine either). But, as Blake declared, "there is no natural religion." 23 Either it is revelation or the slow invention of apostles, commentators, synods, and congregations - or both. Donne's large success and minor failures in Sonnet IV come from what seems a legitimate attempt to dramatize the double encounter.

\section{University of Toronto}

\section{Footnotes}

1 For the Holy Sonnets, the text used is that of Helen Gardner in John Donne, The Divine Poems (Oxford, 1952). Other Donne poems are cited in the edition of John T. Shawcross (Garden City, N.Y., 1967). The sermons are cited in the edition of Evelyn Potter and George Simpson (Berkeley and Los Angeles, 1953-1962). I am indebted to the Canada Council for aid in connection with this essay.

2 I. A. Richards, Practical Criticism (London, 1929), pp. 40-48, 247.

3 Gardner, 1-liii; Stanley Archer, "Meditation and the Structure of Donne's 'Holy Sonnets,"” ELH, 28 (1961), 137 ff; Murray Roston, The Soul of Wit (Oxford, 1974), pp. 62-63; Wilbur Sanders, John Donne's Poetry (Cambridge, 1971), pp. 131-32.

4 Sermons, X, 298.

5 Shawcross, p. 340, n.1.

6 Judah Stampfer, John Donne and the Metaphysical Gesture (New York, 1970), p. 6.

7 Roston, p. 101.

8 John Donne, Pseudo-Martyr (London, 1610), Sig. B3.

9 Sermons, VI, p. 41.

10 Gardner, p. 68.

11 Sermons, IV, pp. 63-88; see Gardner, p. 68.

12 Introd. by G. W. Buchanan, xiv, to R. H. Charles, Eschatology (New York, 1963), and see Rudolf Bultmann, The Presence of Eternity (New York, 1957), pp. 151-55.

13 See Evelyn Simpson, A Study of the Prose Works of John Donne (Oxford, 19.48), p. 87.

14 Sermons, I, pp. 271-72.

15 See William Mueller, John Donne: Preacher (Princeton, 1962), pp. 183 ff.

16 Mueller, $190 \mathrm{ff}$.

17 Mueller, pp. $164 \mathrm{ff}$, usefully gathers and analyses Donne's views on these topics.

18 Sermons, V, p. 173.

19 Sermons, V, pp. 316-17.

20 The discussion which follows is indebted to Gardner xliii-xlvii.

21 Pseudo-Martyr, sig. B3.

22 Gardner, xliv.

23 See Helen Gardner, Religion and Literature (London, 1971), pp. 134ff. 